\title{
Global Identification of HIF-1 $\alpha$ Target Genes in Benzene Poisoning Mouse Bone Marrow Cells
}

\author{
Zhaodi Man, Xing Meng, Fengxia Sun, Yunqiu Pu, Kai Xu, Rongli Sun, Juan Zhang $₫$, \\ Lihong Yin and Yuepu Pu*
}

Key Laboratory of Environmental Medicine Engineering, Ministry of Education of China, School of Public Health, Southeast University, Nanjing 210009, China;

220162973@seu.edu.cn (Z.M.); dzmx925@126.com (X.M.); 220152915@seu.edu.cn (F.S.);

230149559@seu.edu.cn (Y.P.); 230189311@seu.edu.cn (K.X.); 101012172@seu.edu.cn (R.S.);

101011288@seu.edu.cn (J.Z.); lhyin@seu.edu.cn (L.Y.)

* Correspondence: yppu@seu.edu.cn; Tel./Fax: +86-25-8379-4996

Received: 25 September 2018; Accepted: 9 November 2018; Published: 12 November 2018

check for updates

\begin{abstract}
Benzene is a hematopoietic toxicant, and hematopoietic cells in bone marrow (BM) are one of the main targets for its action, especially hematopoietic stem cells (HSCs). Hypoxia-inducible factor- $1 \alpha$ (HIF-1 $\alpha$ ) is associated with the metabolism and physiological functions of HSCs. We previously found that the mechanism of regulation of HIF- $1 \alpha$ is involved in benzene-induced hematopoietic toxicity. In this study, chromatin immunoprecipitation sequencing (ChIP-Seq) technologies were used to analyze the genome-wide binding spectrum of HIF- $1 \alpha$ in mouse BM cells, and specific HIF- $1 \alpha$ target genes and pathways associated with benzene toxicity were screened and validated. By application of the ChIP-Seq technique, we identified target genes HIF- $1 \alpha$ directly binds to and regulates. Forty-two differentially down-regulated genes containing the HIF- $1 \alpha$ specific binding site hypoxia response element (HRE) were found, of which 25 genes were with biological function. Moreover, the enrichment analysis of signal pathways indicated that these genes were significantly enriched in the Jak-STAT signaling pathway, Natural killer cell mediated cytotoxicity, the Fc epsilon RI signaling pathway, Pyrimidine metabolism, the $\mathrm{T}$ cell receptor signaling pathway, and Transcriptional misregulation in cancer. After verification, 11 genes involved in HSC self-renewal, cell cycle, differentiation, and apoptosis pathways were found to be significantly reduced, and may participate in benzene-induced hematotoxicity. Our study provides a new academic clue for the mechanism of benzene hematotoxicity.
\end{abstract}

Keywords: benzene; HIF-1 $\alpha$; hematopoietic toxicity; ChIP-Seq

\section{Introduction}

Benzene, a ubiquitous environmental pollutant and a recognized human carcinogen [1-4], easily enters the human body through the respiratory tract and skin, which leads to chronic benzene poisoning and hematopoietic dysfunction. The main manifestations of its hematotoxicity are low bone marrow (BM) hyperplasia and peripheral blood cell count [5]. At present, it is believed that the toxicity of benzene is mainly caused by the metabolites of benzene. Benzene and its metabolites can cause hematopoietic toxicity through many mechanisms, such as oxidative damage, gene mutation, and epigenetic change $[5,6]$. The metabolites of benzene include phenol, hydroquinone, catechol, and 1,4-benzoquinone [7]. 1,4-benzoquinone can combine directly with biomolecules to produce reactive oxygen species (ROS), cause lipid peroxidation, and eventually result in acute oxidative damage [8-11].

Hematopoietic stem cells (HSCs) exist in hematopoietic niches. The hypoxic microenvironment helps to maintain their energetic metabolism mainly based on anaerobic glycolysis, which is necessary 
to keep their stemness and quiescence $[12,13]$. It is now well established that HIF- $1 \alpha$ is highly expressed in long term proliferating HSCs [14]. Hypoxia inducing factors, especially cell signaling produced by HIF- $1 \alpha$, maintains the quiescence, survival, and metabolic phenotype of HSCs [15-17]. HIF- $1 \alpha$ not only controls the microenvironment of HSCs through increasing anaerobic glycolysis, but also reduces the production of ROS by inhibiting the activity of nicotinamide adenine dinucleotide phosphate (NADPH) oxidases (NOXs) [18-20]. The hypoxic environment of HSCs is beneficial in reducing the generation of endogenous ROS [21,22].

We previously [23] found that the intracellular levels of ROS in benzene poisoning male C57BL/6 mice at different concentrations were increased with a significant fall in the expression of HIF- $1 \alpha$, indicating that HIF- $1 \alpha$ was involved in damage in the mouse hematopoietic system induced by benzene. Hypoxia inducible factor-1 (HIF-1) is a heterodimeric transcription factor that consists of a constitutively expressed subunit, hypoxia-inducible factor- $1 \beta$ (HIF- $1 \beta)$, and a subunit regulated by the cellular $\mathrm{O}_{2}$ concentration, HIF-1 $\alpha$ [23-25]. Under the condition of hypoxia, the pathway of ubiquitination and proteasomal degradation is blocked, which results in stable HIF-1 $\alpha$ protein expression. Thus, HIF- $1 \alpha$ combines with the $\beta$ subunit (HIF-1 $\beta$ ) to form HIF-1, then translocates into the nucleus. The transcriptional coactivator p300 (CBP/p300) binds to the hypoxia response element (HRE) sequence on the downstream gene to initiate or enhance the transcription of the effector gene [26-28]. Finally, many pathways are regulated, such as cell proliferation, apoptosis, angiogenesis, and erythrocyte maturation [29]. HRE is the DNA-binding site of HIF-1 $\alpha$. The target genes of HIF-1 $\alpha$, such as Vascular endothelial growth factor (VEGF), Erythropoietin (EPO) [30,31], phosphoglycerate kinase 1 (PGK1), Lactate dehydrogenase A (LDHA) [32], insulin-like growth factor (IGF) [33], and Bmi1 [34,35], have the site sequence on the HRE.

Regulation of HIF- $1 \alpha$ is essential in bone marrow hematopoietic toxicity induced by benzene, but the specific mechanism has not been clarified. Chromatin immunoprecipitation sequencing (ChIP-Seq) is a high throughput method for detecting DNA histone modification in the whole genome by combining ChIP with sequencing technology. There are many HIF- $1 \alpha$ target genes, and little is known whether these target genes are related to benzene hematotoxicity. In this study, ChIP-Seq was used to analyze the genome-wide binding spectrum of HIF- $1 \alpha$ in mouse bone marrow cells. The purpose of this research is to explore specific HIF- $1 \alpha$ downstream target genes and pathways by which HIF- $1 \alpha$ participates in hematotoxicity caused by benzene.

\section{Materials and Methods}

\subsection{Reagents}

1,4-Benzoquinone and 37\% formaldehyde solution were purchased from Sigma Co. (Sigma, St. Louis, MO, USA). Corn oil was obtained from COFCO (Beijing, China). The Chip Enzymatic Chromatin IP Kit was purchased from Univ Corp (CST, Danvers, MA, USA). The HIF-1 $\alpha$ antibody was supplied by Univ Corp (NOVUS, Littleton, CO, USA).

\subsection{Animals, Treatments, and Blood Routine Examination}

Male C57BL/ 6 mice aged 5-6 weeks (weighing $20 \mathrm{~g} \pm 2 \mathrm{~g}$ ) were purchased from the Animal Core Facility of Nanjing Medical University. Mice $(n=24)$ were randomly divided into three groups and exposed to benzene (vehicle: corn oil) at doses of $0 \mathrm{mg} / \mathrm{kg}$ body weight (b.w.) (Control, C), $150 \mathrm{mg} / \mathrm{kg}$ b.w. (Low Benzene, LB), and $300 \mathrm{mg} / \mathrm{kg}$ b.w. (High Benzene, HB) by subcutaneous injections for 15 consecutive days. The mice were killed by dislocation of cervical vertebrae. After $75 \%$ alcohol immersion for $5 \mathrm{~min}$, the hind limbs of the mice were cut with scissors, and the skin and muscles were removed. The bone was cut off at both ends to expose the bone marrow cavity. Bone marrow cells were obtained by washing the bone marrow cavity with $1 \mathrm{~mL}$ of sterile phosphate buffered saline (PBS) using a syringe. The whole bone marrow cells were collected and fixed, then the HIF-1 $\alpha$ antibody was used to capture the chromatin for later experiments. During the process of exposure, the general 
changes of mental status, behavioral activities, and food intake of the mice were observed daily. Blood samples were taken from eyeballs (EDTA anticoagulant). Hematological parameters, such as white blood cells (WBC), red blood cells (RBC), and platelets (Plt), were measured by an automatic blood cell counting instrument. This study has been approved by the Research Ethics Committee of the Southeast University (approval number: 20140618).

\subsection{Chromatin Immunoprecipitation (ChIP) Assay}

Approximately $4 \times 10^{6} \mathrm{BM}$ cells were required per experiment. Briefly, cells were cross-linked

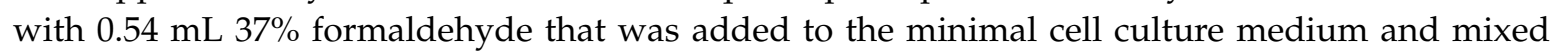
thoroughly for $10 \mathrm{~min}$ at room temperature, and the crosslinking was then quenched with $2 \mathrm{~mL}$ $10 \times$ glycine for $5 \mathrm{~min}$. Cross-linked cells were washed twice with ice-cold PBS, and resuspended in $1 \mathrm{~mL}$ ice-cold lysis buffer with $5 \mu \mathrm{L}$ protease inhibitor cocktail (PIC) and $5 \mu \mathrm{L}$ phenyl-methylsulfonyl fluoride (PMSF). Cells were then resuspended and incubated on ice for $30 \mathrm{~min}$. Subsequently, cell lysate was sonicated to shear chromatin to an average length of 150-900 base pairs (bp) and centrifuged for $10 \mathrm{~min}$ at $15,000 \mathrm{rpm}$ in a $4{ }^{\circ} \mathrm{C}$ microcentrifuge. To each reaction tube, $10 \mu \mathrm{g}$ sheared chromatin DNA was added, followed by $1 \times$ ChIP buffer to a total volume of $500 \mu \mathrm{L}$, and then it was mixed on ice. Ten microliters of the samples were absorbed from each tube as $2 \%$ samples for input control (Input). Ten micrograms of chromatin was immunoprecipitated overnight at $4{ }^{\circ} \mathrm{C}$ with $2 \mu \mathrm{L}$ of HIF- $1 \alpha$ antibody (NOVUS), and $2 \mu \mathrm{L}$ of control IgG antibody (Cell Signaling) or $10 \mu \mathrm{L}$ of negative control protein $\mathrm{H} 3$ antibody (Cell Signaling). Thirty microliter Protein G Magnetic Beads (Millipore) were added and incubated for $2 \mathrm{~h}$ at $4{ }^{\circ} \mathrm{C}$. Beads were successively washed with $1 \mathrm{~mL}$ of different buffers: Low-salt immune complex wash buffer ( $300 \mu \mathrm{L} 10 \times \mathrm{ChIP}$ buffer, $2.7 \mathrm{~mL}$ water) and high-salt immune complex wash buffer $(100 \mu \mathrm{L} 10 \times$ ChIP buffer, $900 \mu \mathrm{L}$ water). Fifty microliters of the reverse cross-linking buffer was added to the eluted chromatin and the supernatant was then transferred. Finally, all tubes were incubated with $6 \mu \mathrm{L}$ of $5 \mathrm{~mol} / \mathrm{L} \mathrm{NaCl}$ and $2 \mu \mathrm{L}$ of proteinase $\mathrm{K}$ at $65{ }^{\circ} \mathrm{C}$ for $2 \mathrm{~h}$. The DNA was purified by centrifuge column. The DNA from ChIP was quantified via Quant IT fluorescence assay (Life Technologies, Waltham, MA, USA). Illumina sequencing libraries were generated with the NEBNext ${ }^{\circledR}$ Ultra $^{\text {TM }}$ DNA Library Prep Kit (New England Biolabs, Ipswich, MA, USA) following the manufacturer's manual. The library quality was determined by using the Agilent 2100 Bioanalyzer (Agilent, Santa Clara, CA, USA), and then subjected to high-throughput $150 \mathrm{bp}$-end sequencing on a Illumina Hiseq sequencer.

\subsection{Data Analysis}

The genes corresponding to the differentially enriched peak located in the promoter region were selected by reference to the specific binding site HRE (aCGTG/gCGTG) of HIF- $1 \alpha$. Then, based on the location of the corresponding chromosomal sequences of each gene, the Mouse GRCm $38 / \mathrm{mm} 10$ database of UCSC was used to find out whether there was a gene sequence corresponding to the differential enrichment peak in these gene sequences. If the HRE site of HIF- $1 \alpha$ was found in this sequence, it was initially judged to be a positive gene. Afterwards, the positive genes that were initially screened in the previous step were searched in the Pubmed database for the biological function (gene ontology (GO) biological function). And the genes with clear function were again considered as positive genes.

\subsection{Real-Time $P C R$}

The screened differentially expressed genes were verified by RT-PCR. The reaction system was $20 \mu \mathrm{L}$ (Table 1). Primers are shown in Table 2. After RNA extraction, reverse transcription of RNA to cDNA was performed with PrimeScript TM RT Master Mix. The program thermocycler of PCR was performed as follows: The program was started with an initial melt step at $95^{\circ} \mathrm{C}$ for $30 \mathrm{~s}$, then $95^{\circ} \mathrm{C}$ for $5 \mathrm{~s}, 60^{\circ} \mathrm{C}$ for $34 \mathrm{~s}$, and run for 40 cycles. The $\beta$-actin was taken as the internal reference gene, and the 
relative expression level of genes was calculated by the $2^{-\Delta \Delta C(t)}$ method. The concentration of cDNA we used in the study was $500 \mathrm{ng} / \mu \mathrm{L}$.

Table 1. RT-PCR mixture.

\begin{tabular}{cc}
\hline Reagent & Volume \\
\hline DNase/RNase-Free Water & $6 \mu \mathrm{L}$ \\
SYBR Green PCR Master mix (Toyobo) & $10 \mu \mathrm{L}$ \\
Forward /Reverse primer $(100 \mu \mathrm{M})$ & $0.8 \mu \mathrm{L}$ \\
ROX Reference Dye & $0.4 \mu \mathrm{L}$ \\
cDNA & $2 \mu \mathrm{L}$ \\
\hline
\end{tabular}

Table 2. PCR primer sequences of HIF- $1 \alpha$ target genes.

\begin{tabular}{ccc}
\hline Gene & Forward Primer & Reverse Primer \\
\hline$\beta$-actin & CTATGCTCTCCCTCACGCCA & TCACGCACGATTTCCCTCTC \\
Ptp4a3 & CCTGTAAGGCAGCCCCAACTA & GTGTCTTAGCCAGGGTTTTATG \\
Samd4 & CAGACGAGGAAGAGTAGAGGG & ACAGACGCATTACTATCACCAA \\
Ifitm3 & GAGGACCAAGGTGCTGATGTT & TAGCCTATGCCTACTCCGTGAA \\
Gzmb & GCCAGTCTTTGCAGTCCTTTA & CTCTGATTACCCATCGTCCCT \\
Acta1 & CCTTCTGACCCATACCTACCAT & AAGCCTCACTTCCTACCCTCG \\
Rbm45 & TTTAGGTTCAGCCAAGAGTGC & CGGGAGAAGTTCAAGGTGTAT \\
Capn5 & TGATTCCTCTTAGCCTCGTCA & GTGGATTTCACAGGTGGTGTT \\
Rps3a1 & AGCAAGGCTCACTTCAAACAC & TTAGGAACATCGGGAAGACAC \\
Ipo4 & AGCCACTCCTCCATGTCTTCC & CATCTTTGGGTTGGGCGTACT \\
Asb15 & GAGCCTCAGCATAATCTCATC & TATACTTCGCCGTCTCCAATA \\
Rabgap11 & AGAGGCGGCTTAGTTGTTTGG & GCGGTCTACCTGTTGATTGCC \\
\hline
\end{tabular}

\subsection{Statistical Analysis}

Differences among multiple groups were analyzed by one-way analysis of variance (ANOVA) using SPSS 16.0 software (SPSS, Chicago, IL, USA). The comparison between the two groups was conducted by the least significant difference (LSD) test. All data was expressed by mean plus and minus standard deviation. The $p$ values $<0.05$ were considered statistically significant.

\section{Results}

\subsection{Benzene Induced Hematopoietic Toxicity and Increased ROS in Mice}

Our previous study [23] demonstrated that red blood cells (RBC), white blood cells (WBC), hemoglobin (Hgb), and platelets (Plt) decreased significantly in $150 \mathrm{mg} / \mathrm{kg}(\mathrm{LB})$ and $300 \mathrm{mg} / \mathrm{kg}(\mathrm{HB})$ groups, along with a fall in the proportion of HSCs (Control, $0.12 \%$; LB, $0.03 \% ; \mathrm{HB}, 0.03 \% ; p<0.05$ ) [23]. There was a distinct increase in the ROS level at a dose of $150 \mathrm{mg} / \mathrm{kg}$. Therefore, the following chip samples of the benzene exposure group were selected for the LB group. Finally, according to the results of blood routine, two samples with obvious differences from the LB group and two samples from the control group were selected (L1, L2, C1, C2).

\subsection{ChIP-Seq Analysis}

The DNA fragments were randomly fragmented by sonication treatment, and the sequenced DNA fragments terminal was mapped at different positions on the genome. Assuming each fragment was 50 in the 200 300 bp region, it was extended and the resulting signal map ("coverage") was visualized as a typical peak shape. The actual DNA sequence combined by HIF- $1 \alpha$ should be located at the maximum point (bottom) of the coverage map; that is, an enriched peak (Figure 1A). After sequencing, image recognition, base calling, and quality filtering, high quality reads (Raw Data) were generated from the Illumina sequencer (Table 3). Then, trimming the joint sequence, the trimmed reads were aligned to the mouse reference genome (UCSC MM10) for peak calling. By comparing the enriched peak with the mouse genome in the UCSC RefSeq database, the enriched peaks were divided into promoter peaks, 
upstream peaks, intron peaks, exon peaks, and intergenic peaks (Figure 1B,C). Then the differentially enriched peaks (DEPs) were further identified by diffReps software and annotated with the latest UCSC RefSeq database to connect the peak information with the gene annotation. Taking advantage of the promoter region (transcriptional start site, TSS-2000 TSS+2000) on the genes corresponding to the enriched peaks, we performed GO functional analysis and Kyoto Encyclopedia of Genes and Genomes (KEGG) pathway analysis to annotate, and speculated the biological functions and pathways that these peaks may participate in.

To gain further insight into biological pathways associated with the significantly up or down-regulated genes identified by HIF- $1 \alpha$, analysis using the Database for Annotation, Visualization, and Data quality control (QC) bioinformatics tool was performed (Table 4, Figure 2).

A

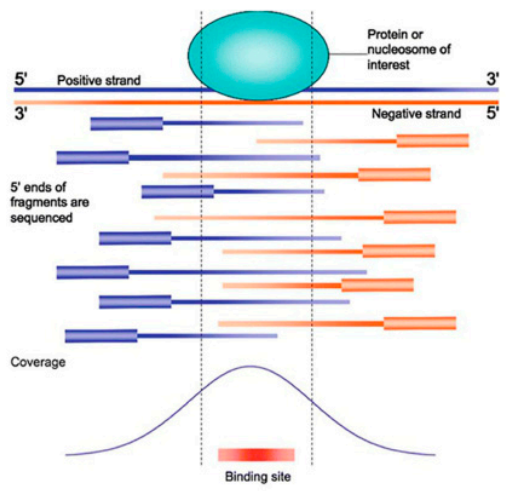

$\mathrm{C}$

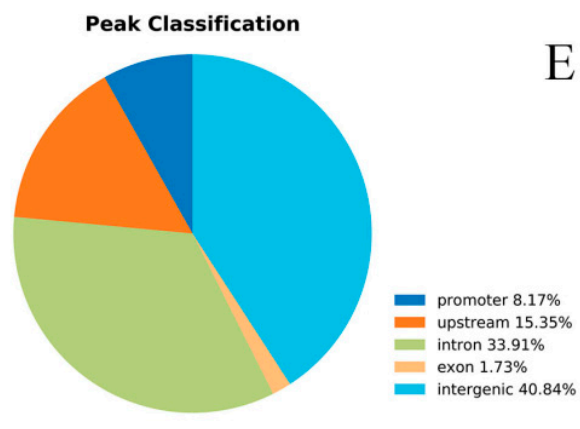

B

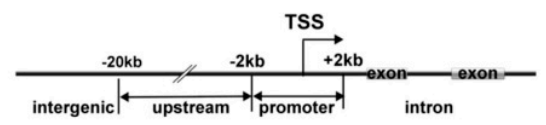

$\mathrm{D}$

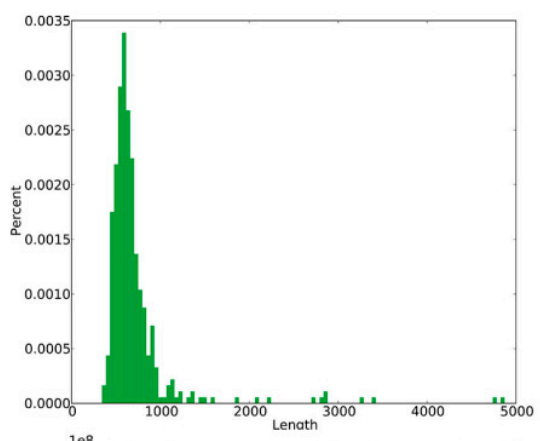

$\mathrm{E}$

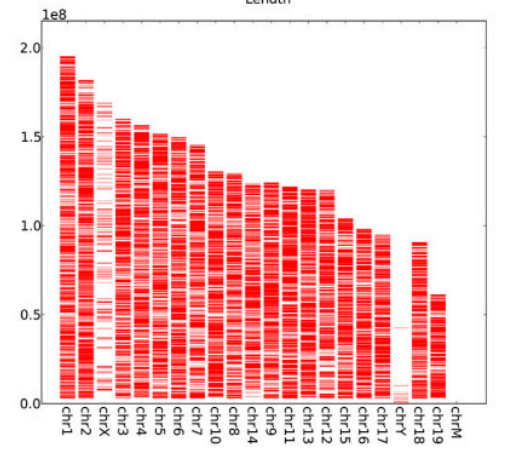

Figure 1. The results of chromatin immunoprecipitation sequencing (ChIP-Seq). Two samples from the low benzene (LB) group and two samples from the control group were selected. (A) Enriched peak. (B) Peak annotation. The enriched peaks were identified and classified as follows: Promoter peaks, upstream peaks, intron peaks, exon peaks, and intergenic peaks. (C) Peaks classification. Of the total generated significant peaks in the control sample $(p<0.0001), 8.17 \%$ were within the promoter region, $33.9 \%$ were within introns, and $40.84 \%$ were within the intergenic region. (D) Peak length distribution. The length distribution of the enrichment peak is calculated to infer the length of the DNA binding region. (E) ChIP-Seq peaks over chromosomes. The distribution of peaks in the genome was statistically enriched, and the chromosomes in the DNA binding region were viewed as a whole.

Table 3. Sequencing reads statistics of the ChIP experiment.

\begin{tabular}{cccc}
\hline Name & Raw Reads & Mapped to Reference Genome & Mapped Percentage \\
\hline C-Input & $13,294,498$ & $13,049,446$ & $98.16 \%$ \\
C1-IP & $16,759,284$ & $16,585,336$ & $98.96 \%$ \\
C2-IP & $15,330,270$ & $14,798,086$ & $96.53 \%$ \\
L-Input & $14,177,435$ & $13,932,833$ & $98.27 \%$ \\
L1-IP & $17,959,618$ & $17,666,744$ & $98.37 \%$ \\
L2-IP & $16,528,262$ & $15,512,603$ & $93.86 \%$ \\
\hline
\end{tabular}


Table 4. Quality control (QC) of the ChIP experiment.

\begin{tabular}{cccccc}
\hline Sample Name & Size (bp) & $\begin{array}{c}\text { Concentration } \\
(\mathbf{n g} / \boldsymbol{\mu L})\end{array}$ & $\begin{array}{c}\text { Concentration } \\
(\mathbf{n m o l} / \mathbf{L})\end{array}$ & Volume $(\boldsymbol{\mu L})$ & Total Amount (ng) \\
\hline C-Input & 304 & 7.98 & 39.8 & 20 & 159.6 \\
C1-IP & 336 & 9.71 & 43.7 & 20 & 194.2 \\
C2-IP & 301 & 10.02 & 50.5 & 20 & 200.4 \\
L-Input & 296 & 7.44 & 38.1 & 20 & 148.8 \\
L1-IP & 298 & 10.74 & 54.6 & 20 & 214.8 \\
L2-IP & 298 & 10.83 & 55.1 & 20 & 216.6 \\
\hline
\end{tabular}

A
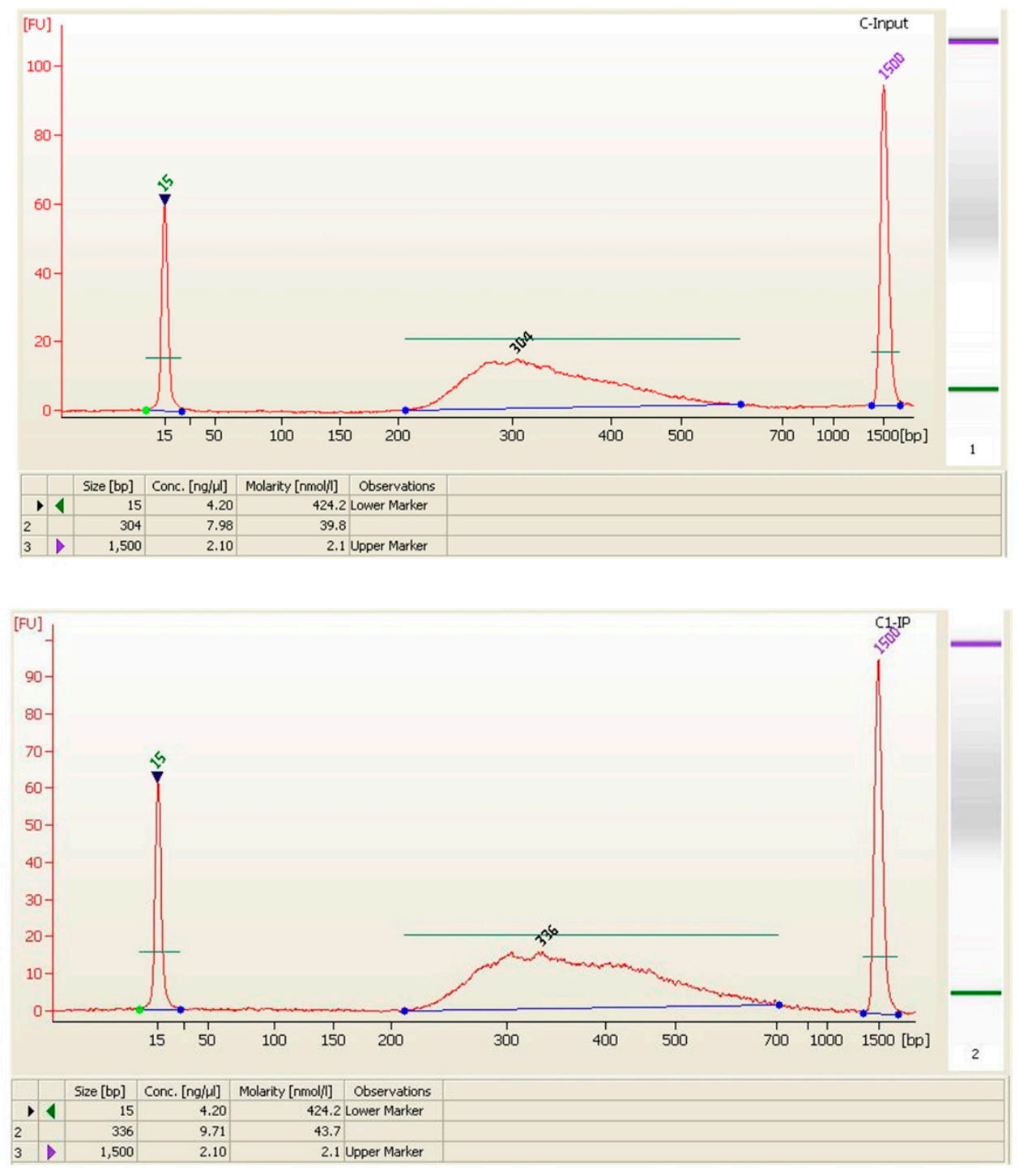

Figure 2. Cont. 

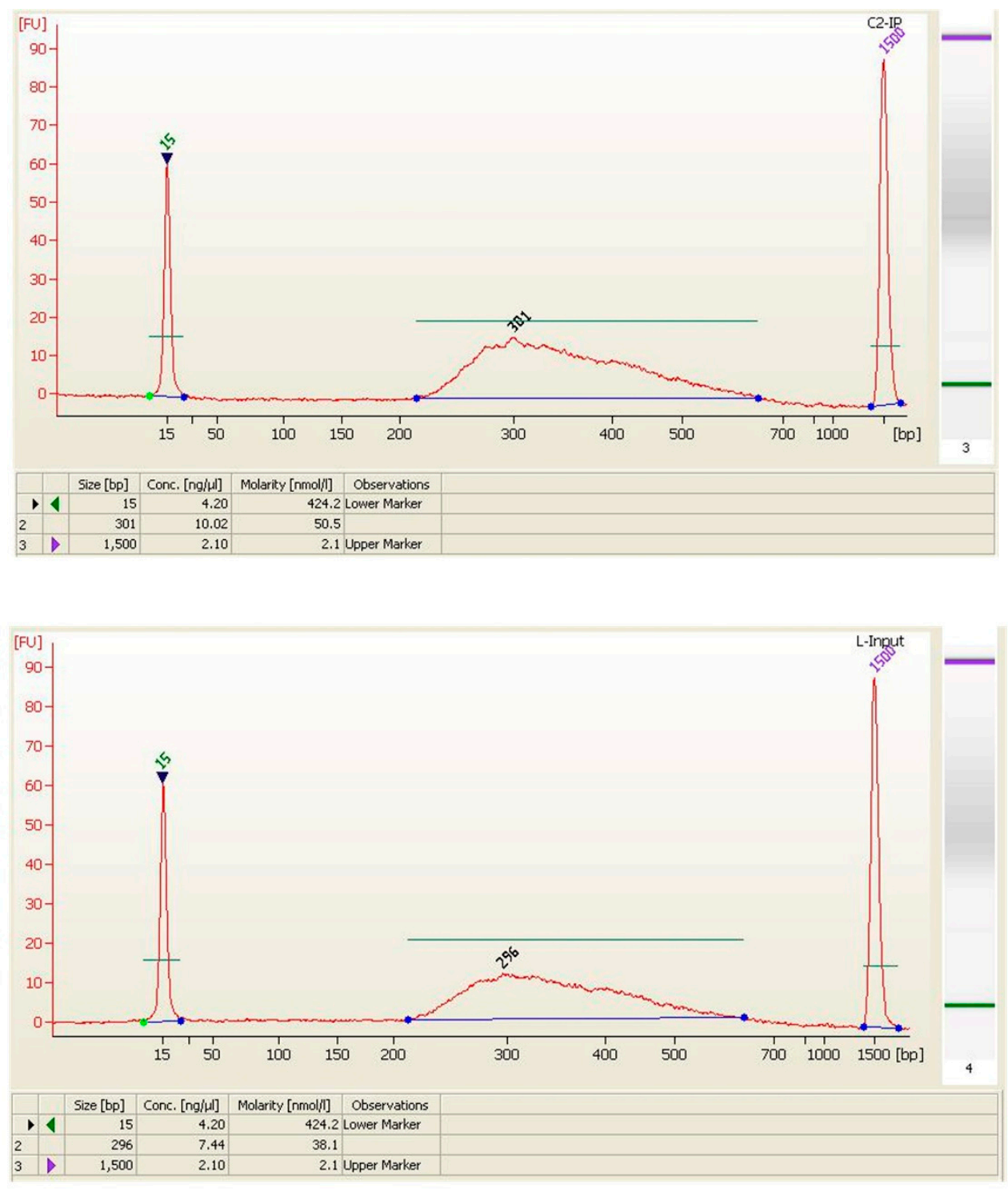

D

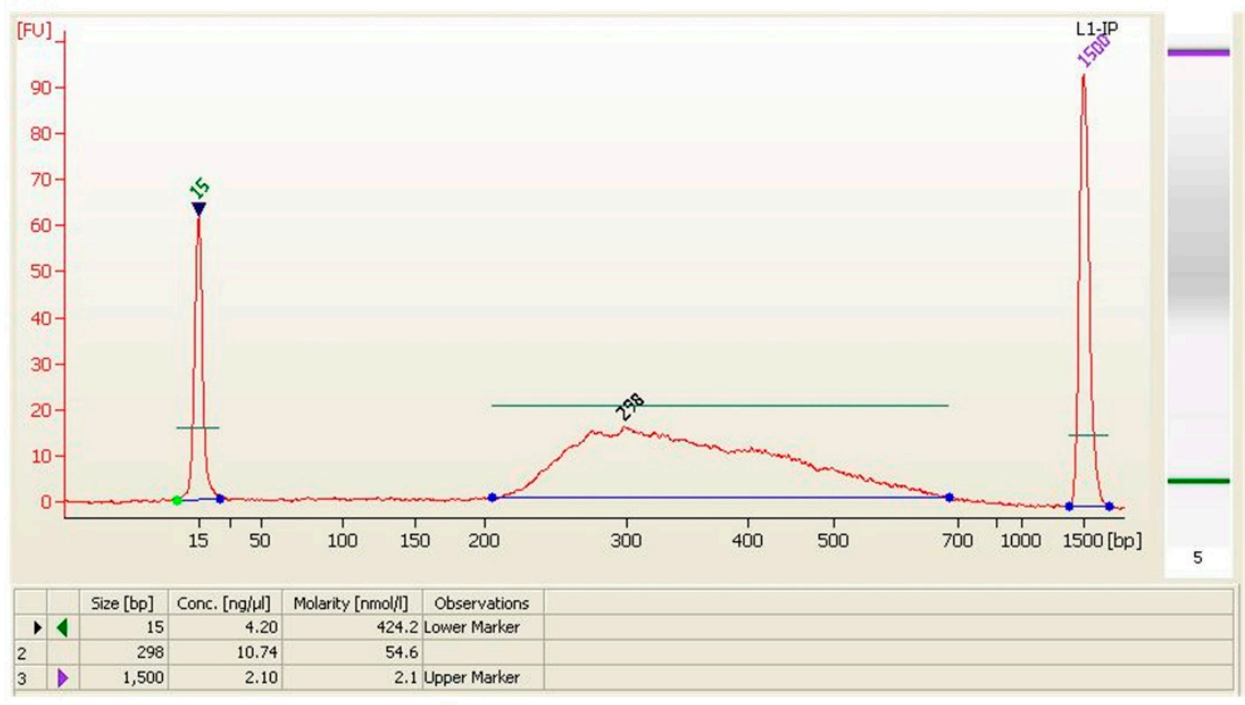

Figure 2. Cont. 


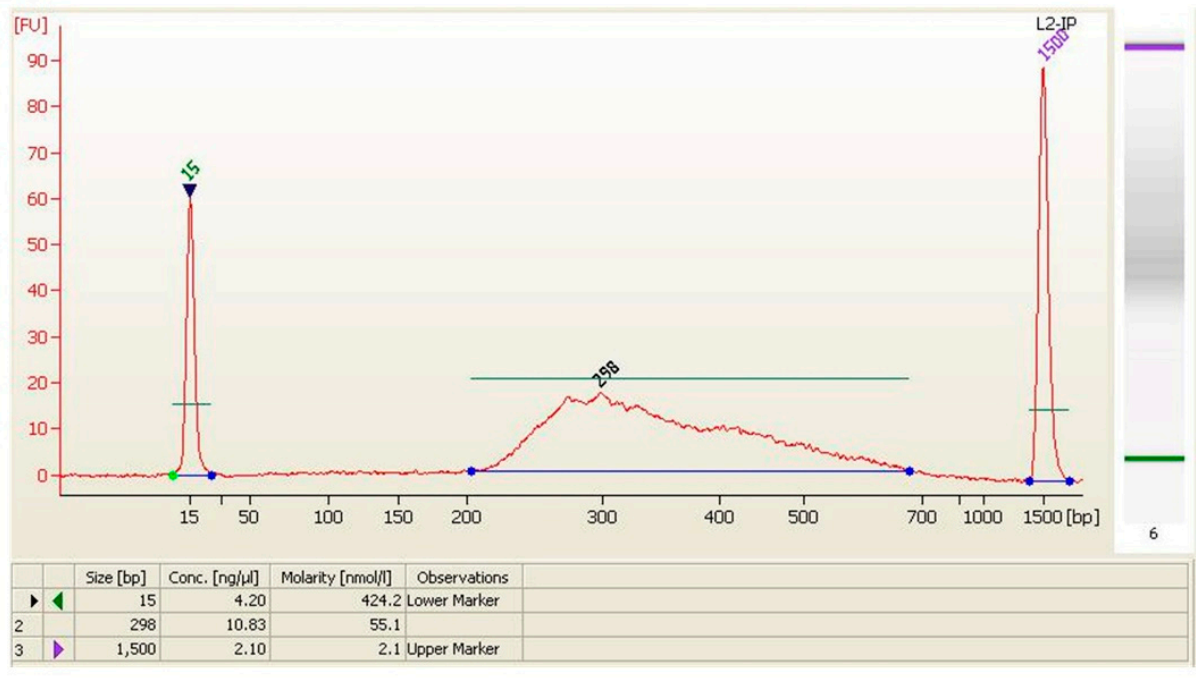

Figure 2. Quality evaluation of control and LB groups by sequencing library. Two samples from the LB group and two samples from the control group were selected (L1, L2, C1, C2). (A) C-Input; (B) C1-IP; (C) C2-IP; (D) L-Input; (E) L1-IP; (F) L2-IP.

\subsection{Screening of HIF-1 $\alpha$ Responsive Genes}

The reduced differential enrichment peak was located in the promoter region, and then the peak was matched to the corresponding gene. A total of 353 up-regulated and 245 down-regulated enrichment peaks in the promoter region were found in the LB group. The top 15 significantly up-regulated or down-regulated genes were chosen and are shown in Table 5. Among the 245 down-regulated genes, 42 genes containing the HIF- $1 \alpha$ specific binding site HRE (aCGTG/gCGTG) in the gene sequence of the differentially enriched region were selected using the UCSC database.

Therefore, we preliminarily confirmed that 42 response genes were the target gene of HIF- $1 \alpha$. By searching for the function in the Pubmed database, we found that there were 25 genes involved in the following functions: Promoting cell proliferation, migration, invasion, growth, and metastasis. Thus, these genes were selected for further validation.

Table 5. Significantly changed genes corresponding to the differentially enriched peak.

\begin{tabular}{cccccc}
\hline Down-Regulated Gene Name & Fold Change & FDR & Up-Regulated Gene Name & Fold Change & FDR \\
\hline Olfr1120 & -138.5 & 0.000 & Fpgt & 128.8 & 0.005 \\
Hilpda & -116.3 & 0.003 & Lrriq3 & 128.8 & 0.005 \\
Ebag9 & -116.3 & 0.003 & Pitpnm2 & 113.6 & 0.007 \\
Ptp4a3 & -105.4 & 0.002 & Rspry1 & 111 & 0.006 \\
Rgs1 & -105.4 & 0.002 & Fam192a & 111 & 0.006 \\
Tmc1 & -99.9 & 0.005 & Otud1 & 106 & 0.007 \\
Snx33 & -94.4 & 0.007 & Rab5c & 104.3 & 0.010 \\
Spred3 & -94.3 & 0.007 & Edn3 & 102.3 & 0.004 \\
Snhy17 & -94.3 & 0.007 & Ccdc88a & 97.3 & 0.007 \\
Olfr113 & -94.3 & 0.007 & Sod2 & 96.7 & 0.012 \\
Commd9 & -89 & 0.005 & Sept9 & 96.7 & 0.012 \\
Rhno1 & -89 & 0.005 & C330013E15Rik & 96.1 & 0.012 \\
Foxm1 & -89 & 0.005 & Dynll1 & 95.5 & 0.012 \\
Pgm5 & -88.9 & 0.005 & Gm13830 & 95.5 & 0.012 \\
Mug1 & -88.8 & 0.009 & Asnsd1 & 94.1 & 0.007 \\
Samd4 & -88.8 & 0.009 & 4930486L24Rik & 90.4 & 0.012 \\
\hline
\end{tabular}

Note. FDR: The corrected p-value between control $(0 \mathrm{mg} / \mathrm{kg}, \mathrm{C})$ and benzene exposure $(150 \mathrm{mg} / \mathrm{kg}$, LB) groups. 


\subsection{Gene Ontology (GO) Analysis}

The ontology covers three domains: Biological Process (BP), Cellular Component (CC), and Molecular Function (MF). It is interesting to note that GOBP terms were related to the cellular process, phosphorus metabolic process, phosphate-containing compound metabolic process, cellular response to stress, and MAPK cascade (Figure 3).

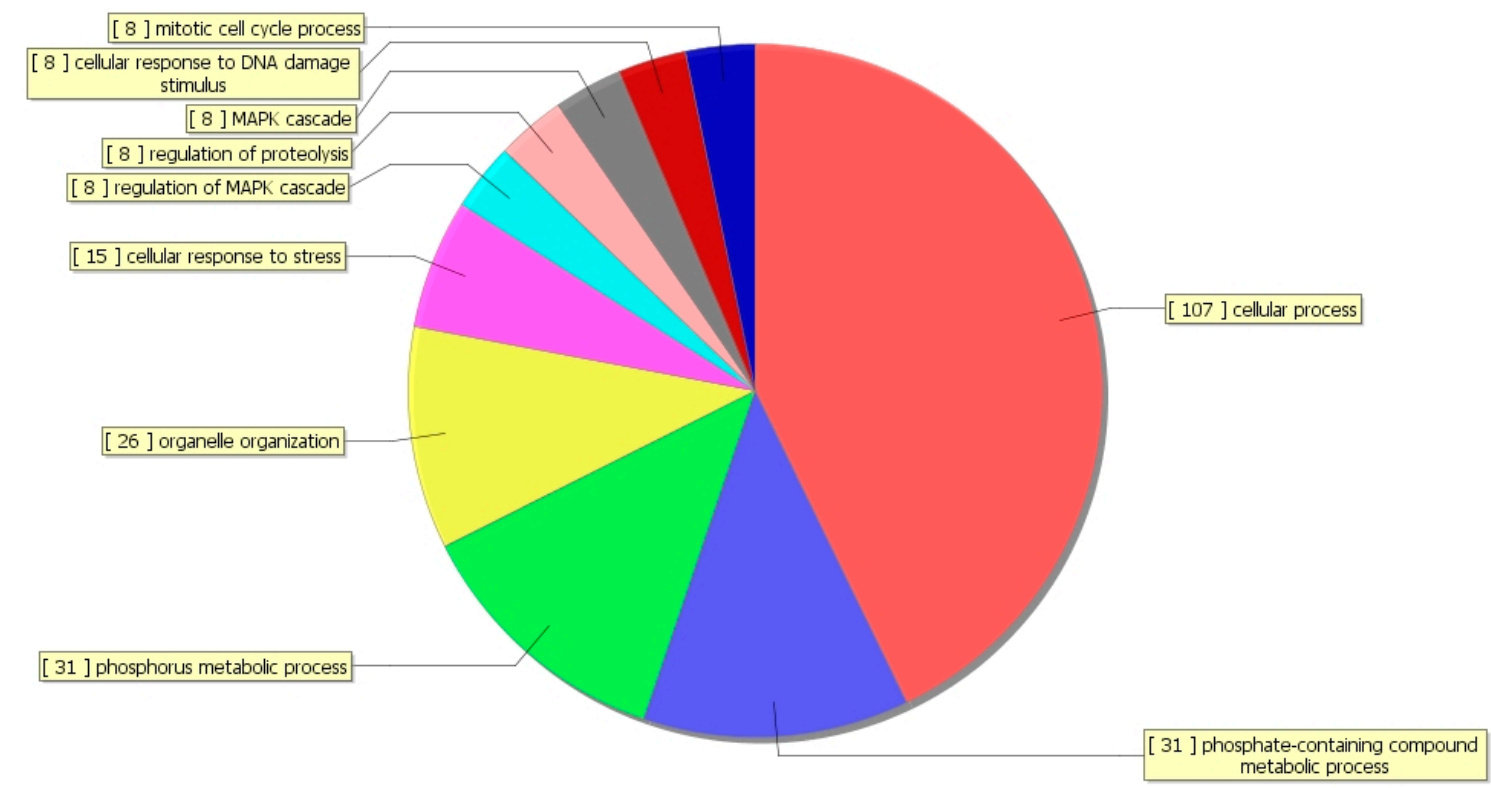

Figure 3. Gene ontology (GO) biological process classification. The pie chart shows the GO biological process (GOBP) sequencing result of genes corresponding to the reduced enrichment peak in the $150 \mathrm{mg} / \mathrm{kg}$ (LB) group compared to the control group, with the top ten counts of the significant enrichment terms.

\subsection{Kyoto Encyclopedia of Genes and Genomes (KEGG) Analysis}

The genes corresponding to the differentially enriched peaks in the promoter region (TSS-2000 TSS+2000) were used to analyze the pathway, in order to elucidate and speculate the pathways in which these enriched peaks (proteins) may be involved. Similarly, Figure 4 displays the KEGG pathway, which was significantly enriched in the HIF- $1 \alpha$ responsive gene corresponding to the reduced enrichment peaks expressed in the LB benzene treatment group compared with the control group, including the Jak-STAT signaling pathway, Natural killer cell mediated cytotoxicity, Fc epsilon RI signaling pathway, Pyrimidine metabolis, $\mathrm{T}$ cell receptor signaling pathway, and Transcriptional misregulation in cancer. The actually matched HIF- $1 \alpha$ responsive gene count and name are displayed in Table 6 . 
Sig pathway of DE gene

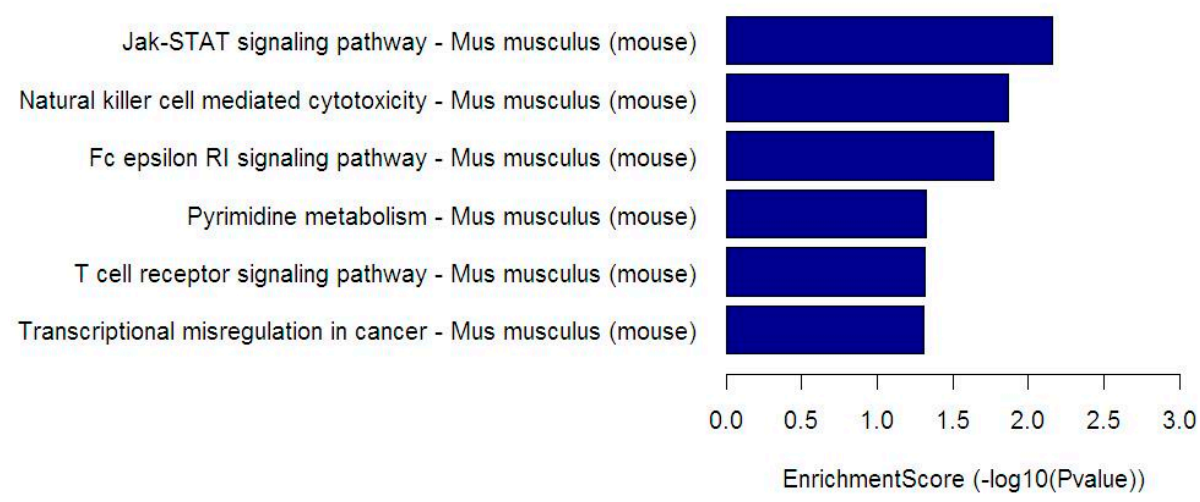

Figure 4. Kyoto Encyclopedia of Genes and Genomes (KEGG) pathway associated with HIF-1 $\alpha$ responsive genes. Through bioinformatics analysis, multiple pathways of HIF- $1 \alpha$ differentially binding target genes and HIF- $1 \alpha$ coregulated genes were obtained in mice bone marrow (BM) cells compared with the control group. The HIF- $1 \alpha$ target genes, which correspond to the reduced enrichment peak in the $150 \mathrm{mg} / \mathrm{kg}$ (LB) group, were significantly enriched in the KEGG signaling pathway.

Table 6. Pathway Results.

\begin{tabular}{cccc}
\hline Pathway & Total & Hits & Target Gene Name \\
\hline Jak-STAT signaling pathway & 155 & 5 & CSF2RA, GRB2, PIK3CA, SPRED2, SPRED3 \\
Natural killer cell mediated cytotoxicity & 119 & 4 & GRB2, GZMB, LCP2, PIK3CA \\
Fc epsilon RI signaling pathway & 70 & 3 & GRB2, LCP2, PIK3CA \\
Pyrimidine metabolism & 104 & 3 & CTPS, NT5C3B, TXNRD1 \\
T cell receptor signaling pathway & 105 & 3 & GRB2, LCP2, PIK3CA \\
Transcriptional misregulation in cancer & 178 & 4 & BCL2A1C, GZMB, JMJD1C, LYL1 \\
\hline
\end{tabular}

Note. Total represents the total count of the genes in the listed pathway. Hits is the actually matched enriched gene number in the pathway.

\subsection{Validation of HIF-1 $\alpha$ Target Gene}

The mRNA level of HIF-1 $\alpha$ target genes was detected in BM cells of C57BL/ 6 mice between the benzene exposure and control groups by RT-PCR. Then the results of RT-PCR and ChIP-Seq were analyzed together to screen out candidate critical genes. The mRNA level of 11 out of 25 genes was down-regulated in BM cells in $150 \mathrm{mg} / \mathrm{kg}$ (LB) and $300 \mathrm{mg} / \mathrm{kg}$ (HB) benzene-exposed mice compared with the control group (Table 7).

Table 7. Validation of differentially deregulated genes by RT-PCR.

\begin{tabular}{ccc}
\hline \multirow{2}{*}{ Gene } & \multicolumn{2}{c}{$\mathbf{2}^{-\Delta \Delta C(\mathbf{t})}$} \\
\cline { 2 - 3 } & $\mathbf{L B} / \mathbf{C}$ & $\mathbf{H B} / \mathbf{C}$ \\
\hline Ptp4a3 & $0.11985^{* * *}$ & $0.07554^{* * *}$ \\
Samd4 & $0.10351^{* * *}$ & $0.04879^{* * *}$ \\
Ifitm3 & $0.39707^{*}$ & $0.53172^{*}$ \\
Gzmb & 0.41548 & $0.35731^{*}$ \\
Acta1 & $0.06175^{* *}$ & $0.11185^{*}$ \\
Rbm45 & $0.70175^{* *}$ & $0.49878^{* *}$ \\
Capn5 & $0.08935^{* * *}$ & $0.06172^{* * *}$ \\
Rps3a1 & $0.48881^{* * *}$ & $0.57754^{* *}$ \\
Ipo4 & $0.39123^{* *}$ & $0.31920^{* *}$ \\
Asb15 & $0.09352^{* *}$ & $0.25600^{* *}$ \\
Rabgap11 & $0.23461^{* * *}$ & $0.41362^{* *}$ \\
\hline
\end{tabular}

Note. Transcriptional level of HIF-1 $\alpha$ target genes in mouse bone marrow cells. Eleven genes were validated in $150 \mathrm{mg} / \mathrm{kg}$ (LB) and $300 \mathrm{mg} / \mathrm{kg}$ (high benzene, HB) doses. * Significant difference compared to the control group, $p<0.05$. ${ }^{* *}$ Significant difference compared to the control group, $p<0.01$. ${ }^{* *}$ Significant difference compared to the control group, $p<0.001$. 


\section{Discussion}

With the wide application of benzene in coatings, dyes, spray paint, and other industries, occupational benzene exposure and its health hazards are important public health issues [36]. Elucidation of the mechanism of benzene toxicity can provide a scientific basis for finding the early damage markers, and is helpful for prevention and treatment strategies for benzene poisoning.

Benzene enters into the human body mainly through respiratory inhalation and skin contact [4]. Part of it is excreted from the body and part metabolized in the liver and BM. Firstly, phenol and catecholamine are produced from benzene under the action of cytochrome oxidase in the liver [7]. Secondly, these compounds are catalyzed by myeloperoxidase (MPO) in BM to be the ultimate carcinogen, benzoquinone. BM is an important target organ of benzene toxicity. Therefore, the BM cells of benzene-exposed mice were selected for ChIP-Seq. ROS levels in quiescent stem cells are kept low, thus supporting their ability for long-term repopulation. Survival in this low-oxygen microenvironment requires significant metabolic adaptation [37]. Hypoxia inducible factors (HIFs) are the most direct regulatory factor in the hypoxic environment [38-40], which can regulate oxidative phosphorylation and glycolysis transformation. In the bone marrow microenvironment, the HIF family is involved in glycolytic metabolism, thereby providing sufficient amounts of ATP to maintain HSC activity.

We firstly reported the genome-wide study of HIF-1 $\alpha$ target genes in benzene-exposed mice. Compared with the control group, there were 42 differentially enriched genes in the benzene poisoning group. Through analyzing the GO function and signal pathway of differentially expressed genes, we found that these genes were mainly enriched in signal pathways related to cell apoptosis, differentiation, proliferation, oxidative stress, and the hematopoietic system. In addition, our early results showed that exposure to a certain dose of benzene could induce HIF- $1 \alpha$ degradation, and decrease the proportion of hematopoietic stem cells and number of peripheral blood cells [23]. Thus, the abnormal expression of HIF- $1 \alpha$ and its downstream genes may be involved in benzene-induced hematotoxicity.

The GO function of differentially enriched genes and the RT-PCR analysis of mouse bone marrow cells showed that 11 genes were down-regulated in the benzene exposure group compared with the control group. Among them, ipo4 [41] functions as a transporter of HIF-1 $\alpha$. Ribosomal protein S3a1 (Rps3a1) [42], calpain 5 (Capn5) [43], skeletal muscle $\alpha$-actin 1-encoding gene (Acta1), and ganzyme B (Gzmb) [44] are all related to cell apoptosis and differentiation. The up-regulation of protein tyrosine phosphatase 4A3 (Ptp4a3) [45] activates Src kinase, which promotes many cell signaling pathways, and cell proliferation, growth, and migration. Research has shown that RNA-binding motif protein 45 (RBM45) transfers from nucleus to cytoplasm under oxidative stress, and this redistribution regulates Kelch-like ECH-associated protein 1 (KEAP1) protein levels, thereby inhibiting NF-E2-related factor 2 (NRF2) activity and reducing cellular antioxidant responses. However, activation of NRF2 may temporarily protect HSCs from the harmful effects of ROS. Once the ROS level recovers, it promotes the long-term decline of HSC self-renewal [46]. Elevating ROS levels rise and lead to cell death [47], which is of great importance in cancer therapy strategies. It has been reported that the Rab GTPase activating protein 1-Like (Rabgap1l)-mediated tyrosine kinase signal transduction pathway plays a major role in the pathogenesis of leukemia [15]. The role and mechanism of specific HIF-1 $\alpha$ response genes deserves further study.

Here, the ChIP-Seq technique was used to study the downstream specific genes and signaling pathways regulated by HIF- $1 \alpha$ in benzene-induced hematotoxicity, and to explore the role and molecular mechanism of the ROS mediated HIF- $1 \alpha$ pathway in hematotoxicity caused by benzene. Our results demonstrate that HIF- $1 \alpha$ coregulated with its target genes and pathways in coping with benzene-induced hematopoietic damage. Further research is needed to find the interaction of HIF-1 $\alpha$ target genes in the hematopoietic related signaling pathway. Our study provides new clues for screening critical HIF- $1 \alpha$ responsive genes and elucidating the mechanism of benzene hematotoxicity. 


\section{Conclusions}

Benzene exposure may destroy the bone marrow microenvironment and decrease the expression of HIF- $1 \alpha$, indicating that HIF- $1 \alpha$ plays an important role in benzene-induced hematopoietic damage. It is well known that there are many HIF- $1 \alpha$ target genes, but which of them participate in benzene toxicity remains unclear. In the present study, the HIF- $1 \alpha$ target genes related to benzene toxicity were screened by the ChIP-Seq technique, and we further identified differential HIF- $1 \alpha$ responsive genes and pathways following benzene exposure. Eleven HIF- $1 \alpha$ down-regulated genes were validated as critical genes, which were involved in HSC self-renewal, cell cycle, differentiation, and apoptosis pathways. This study provides new insight into the mechanism of benzene-induced hematopoietic toxicity.

Author Contributions: Conceptualization, Y.P., J.Z. and Z.M.; Methodology, Z.M., Y.P. and K.X.; Software, X.M.; Validation, Z.M., X.M. and F.S.; Formal Analysis, Z.M.; Investigation, Z.M.; Resources, X.M.; Data Curation, Z.M., X.M. and F.S.; Writing-Original Draft Preparation, Z.M.; Writing-Review \& Editing, R.S.; Visualization, Z.M. and R.S.; Supervision, L.Y. and Y.P.; Project Administration, J.Z.; Funding Acquisition, Y.P.

Funding: This research was funded by (the National Natural Science Foundation of China) grant number (81573189, 81730087).

Conflicts of Interest: The authors declare that there are no conflicts of interest.

\section{References}

1. Bird, M.G.; Greim, H.; Kaden, D.A.; Rice, J.M.; Snyder, R. Benzene 2009-Health effects and mechanisms of bone marrow toxicity: Implications for $\mathrm{t}-\mathrm{AML}$ and the mode of action framework. Chem.-Biol. Interact. 2010, 184, 3-6. [CrossRef] [PubMed]

2. McHale, C.M.; Zhang, L.; Smith, M.T. Current understanding of the mechanism of benzene-induced leukemia in humans: Implications for risk assessment. Carcinogenesis 2012, 33, 240-252. [CrossRef] [PubMed]

3. Pyatt, D.W.; Hays, S.M.; English, C.; Cushing, C.A. United States Voluntary Children's Chemical Evaluation Program (VCCEP) risk assessment for children exposed to benzene. Toxicol. Mech. Methods 2012, 22, 81-104. [CrossRef] [PubMed]

4. Santiago, F.; Alves, G.; Otero, U.B.; Tabalipa, M.M.; Scherrer, L.R.; Kosyakova, N.; Ornellas, M.H.; Liehr, T. Monitoring of gas station attendants exposure to benzene, toluene, xylene (BTX) using three-color chromosome painting. Mol. Cytogenet. 2014, 7, 15-21. [CrossRef] [PubMed]

5. Sun, R.; Zhang, J.; Yin, L.; Pu, Y. Investigation into variation of endogenous metabolites in bone marrow cells and plasma in C3H/He mice exposed to benzene. Int. J. Mol. Sci. 2014, 15, 4994-5010. [CrossRef] [PubMed]

6. Fan, R.; Li, J.; Chen, L.; Xu, Z.; He, D.; Zhou, Y.; Zhu, Y.; Wei, F.; Li, J. Biomass fuels and coke plants are important sources of human exposure to polycyclic aromatic hydrocarbons, benzene and toluene. Environ. Res. 2014, 135, 1-8. [CrossRef] [PubMed]

7. Jiang, H.; Lai, Y.; Hu, K.; Wei, Q.; Liu, Y. Human CYP2E1-dependent and human sulfotransferase 1A1-modulated induction of micronuclei by benzene and its hydroxylated metabolites in Chinese hamster V79-derived cells. Mutat. Res. 2014, 770, 37-44. [CrossRef] [PubMed]

8. Ludin, A.; Gur-Cohen, S.; Golan, K.; Kaufmann, K.B.; Itkin, T.; Medaglia, C.; Lu, X.J.; Ledergor, G.; Kollet, O.; Lapidot, T. Reactive oxygen species regulate hematopoietic stem cell self-renewal, migration and development, as well as their bone marrow microenvironment. Antioxid. Redox Signal. 2014, 21, 1605-1619. [CrossRef] [PubMed]

9. Richardson, C.; Yan, S.; Vestal, C.G. Oxidative stress, bone marrow failure, and genome instability in hematopoietic stem cells. Int. J. Mol. Sci. 2015, 16, 2366-2385. [CrossRef] [PubMed]

10. Suda, T.; Takubo, K.; Semenza, G.L. Metabolic regulation of hematopoietic stem cells in the hypoxic niche. Cell Stem Cell 2011, 9, 298-310. [CrossRef] [PubMed]

11. Urao, N.; Ushio-Fukai, M. Redox regulation of stem/progenitor cells and bone marrow niche. Free Rad. Biol. Med. 2013, 54, 26-39. [CrossRef] [PubMed]

12. Snyder, R. The bone marrow niche, stem cells, and leukemia: Impact of drugs, chemicals, and the environment. Ann. N.Y. Acad. Sci. 2014, 1310, 1-6. [CrossRef] [PubMed]

13. Testa, U.; Labbaye, C.; Castelli, G.; Pelosi, E. Oxidative stress and hypoxia in normal and leukemic stem cells. Exp. Hematol. 2016, 44, 540-560. [CrossRef] [PubMed] 
14. Danet, G.H.; Pan, Y.; Luongo, J.L.; Bonnet, D.A.; Simon, M.C. Expansion of human SCID-repopulating cells under hypoxic conditions. J. Clin. Investig. 2003, 112, 126-135. [CrossRef] [PubMed]

15. Forristal, C.E.; Nowlan, B.; Jacobsen, R.N.; Barbier, V.; Walkinshaw, G.; Walkley, C.R.; Winkler, I.G.; Levesque, J.P. HIF-1alpha is required for hematopoietic stem cell mobilization and 4-prolyl hydroxylase inhibitors enhance mobilization by stabilizing HIF-1alpha. Leukemia 2015, 29, 1366-1378. [CrossRef] [PubMed]

16. Regan, J.N.; Lim, J.; Shi, Y.; Joeng, K.S.; Arbeit, J.M.; Shohet, R.V.; Long, F. Up-regulation of glycolytic metabolism is required for HIF1alpha-driven bone formation. Proc. Natl. Acad. Sci. USA 2014, 111, 8673-8678. [CrossRef] [PubMed]

17. Takubo, K.; Nagamatsu, G.; Kobayashi, C.I.; Nakamura-Ishizu, A.; Kobayashi, H.; Ikeda, E.; Goda, N.; Rahimi, Y.; Johnson, R.S.; Soga, T.; et al. Regulation of glycolysis by Pdk functions as a metabolic checkpoint for cell cycle quiescence in hematopoietic stem cells. Cell Stem Cell 2013, 12, 49-61. [CrossRef] [PubMed]

18. Piccoli, C.; D’Aprile, A.; Ripoli, M.; Scrima, R.; Lecce, L.; Boffoli, D.; Tabilio, A.; Capitanio, N. Bone-marrow derived hematopoietic stem/progenitor cells express multiple isoforms of NADPH oxidase and produce constitutively reactive oxygen species. Biochem. Biophys. Res. Commun. 2007, 353, 965-972. [CrossRef] [PubMed]

19. Piccoli, C.; Ria, R.; Scrima, R.; Cela, O.; D’Aprile, A.; Boffoli, D.; Falzetti, F.; Tabilio, A.; Capitanio, N. Characterization of mitochondrial and extra-mitochondrial oxygen consuming reactions in human hematopoietic stem cells. Novel evidence of the occurrence of NAD(P)H oxidase activity. J. Biol. Chem. 2005, 280, 26467-26476. [CrossRef] [PubMed]

20. Urao, N.; McKinney, R.D.; Fukai, T.; Ushio-Fukai, M. NADPH oxidase 2 regulates bone marrow microenvironment following hindlimb ischemia: Role in reparative mobilization of progenitor cells. Stem Cells 2012, 30, 923-934. [CrossRef] [PubMed]

21. Ito, K.; Hirao, A.; Arai, F.; Takubo, K.; Matsuoka, S.; Miyamoto, K.; Ohmura, M.; Naka, K.; Hosokawa, K.; Ikeda, Y.; et al. Reactive oxygen species act through p38 MAPK to limit the lifespan of hematopoietic stem cells. Nat. Med. 2006, 12, 446-451. [CrossRef] [PubMed]

22. Jang, Y.Y.; Sharkis, S.J. A low level of reactive oxygen species selects for primitive hematopoietic stem cells that may reside in the low-oxygenic niche. Blood 2007, 110, 3056-3063. [CrossRef] [PubMed]

23. Meng, X.; Zhang, J.; Yin, L.; Pu, Y. Involvement of hypoxia-inducible factor-1 alpha (HIF-1alpha) in inhibition of benzene on mouse hematopoietic system. J. Toxicol. Environ. Health A 2016, 79, 402-406. [CrossRef] [PubMed]

24. Ciurea, A.V.; Palade, C.; Voinescu, D.; Nica, D.A. Subarachnoid hemorrhage and cerebral vasospasmLiterature review. J. Med. Life 2013, 6, 120-125. [PubMed]

25. Pugh, C.W.; Ratcliffe, P.J. Regulation of angiogenesis by hypoxia role of the HIF system. Nat. Med. 2003, 9, 677-684. [CrossRef] [PubMed]

26. Jaakkola, P.; Mole, D.R.; Tian, Y.-M.; Wilson, M.I.; Gielbert, J.; Gaskell, S.J.; Kriegsheim, A.V.; Hebestreit, H.F.; Mukherji, M.; Schofield, C.J.; et al. Targeting of HIF-alpha to the von Hippel-Lindau ubiquitylation complex by $\mathrm{O}_{2}$-regulated prolyl hydroxylation. Science 2001, 292, 468-472. [CrossRef] [PubMed]

27. Prabhakar, N.R.; Semenza, G.L. Oxygen Sensing and Homeostasis. Physiology 2015, 30, 340-348. [CrossRef] [PubMed]

28. Sahin, E.; Colla, S.; Liesa, M.; Moslehi, J.; Muller, F.L.; Guo, M.; Cooper, M.; Kotton, D.; Fabian, A.J.; Walkey, C.; et al. Telomere dysfunction induces metabolic and mitochondrial compromise. Nature 2011, 470, 359-365. [CrossRef] [PubMed]

29. Kaelin, W.G., Jr.; Ratcliffe, P.J. Oxygen sensing by metazoans: The central role of the HIF hydroxylase pathway. Mol. Cell 2008, 30, 393-402. [CrossRef] [PubMed]

30. Keswani, S.C.; Bosch-Marce, M.; Reed, N.; Fischer, A.; Semenza, G.L.; Hoke, A. Nitric oxide prevents axonal degeneration by inducing HIF-1-dependent expression of erythropoietin. Proc. Natl. Acad. Sci. USA 2011, 108, 4986-4990. [CrossRef] [PubMed]

31. Yoon, D.; Ponka, P.; Prchal, J.T. Hypoxia. 5. Hypoxia and hematopoiesis. Am. J. Physiol. Cell Physiol. 2011, 300, 1215-1222. [CrossRef] [PubMed]

32. Cui, X.-G.; Han, Z.-T.; He, S.-H.; Wu, X.-D.; Chen, T.-R.; Shao, C.-H.; Chen, D.-L.; Su, N.; Chen, Y.-M.; Wang, T.; et al. HIF1 $2 \alpha$ mediates hypoxia-induced LDHA expression in human pancreatic cancer cells. Oncotarget 2017, 8, 24840-24852. [PubMed] 
33. Ren, H.; Accili, D.; Duan, C. Hypoxia converts the myogenic action of insulin-like growth factors into mitogenic action by differentially regulating multiple signaling pathways. Proc. Natl. Acad. Sci. USA 2010, 107, 5857-5862. [CrossRef] [PubMed]

34. Du, R.; Xia, L.; Ning, X.; Liu, L.; Sun, W.; Huang, C.; Wang, H.; Sun, S. Hypoxia-induced Bmi1 promotes renal tubular epithelial cell-mesenchymal transition and renal fibrosis via PI3K/Akt signal. Mol. Biol. Cell 2014, 25, 2650-2659. [CrossRef] [PubMed]

35. Park, I.-K.; Qian, D.; Kiel, M.; Becker, M.W.; Pihalja, M.; Weissman, I.L.; Morrison, S.J.; Clarke, M.F. Bmi-1 is required for maintenance of adult self-renewing haematopoietic stem cells. Nature 2003, 423, 302-305. [CrossRef] [PubMed]

36. Ferrero, A.; Esplugues, A.; Estarlich, M.; Llop, S.; Cases, A.; Mantilla, E.; Ballester, F.; Iniguez, C. Infants' indoor and outdoor residential exposure to benzene and respiratory health in a Spanish cohort. Environ. Pollut. 2017, 222, 486-494. [CrossRef] [PubMed]

37. Simsek, T.; Kocabas, F.; Zheng, J.; Deberardinis, R.J.; Mahmoud, A.I.; Olson, E.N.; Schneider, J.W.; Zhang, C.C.; Sadek, H.A. The distinct metabolic profile of hematopoietic stem cells reflects their location in a hypoxic niche. Cell Stem Cell 2010, 7, 380-390. [CrossRef] [PubMed]

38. Luo, W.; Hu, H.; Chang, R.; Zhong, J.; Knabel, M.; O’Meally, R.; Cole, R.N.; Pandey, A.; Semenza, G.L. Pyruvate kinase M2 is a PHD3-stimulated coactivator for hypoxia-inducible factor 1. Cell 2011, 145, 732-744. [CrossRef] [PubMed]

39. Nishida, C.; Kusubata, K.; Tashiro, Y.; Gritli, I.; Sato, A.; Ohki-Koizumi, M.; Morita, Y.; Nagano, M.; Sakamoto, T.; Koshikawa, N.; et al. MT1-MMP plays a critical role in hematopoiesis by regulating HIF-mediated chemokine/cytokine gene transcription within niche cells. Blood 2012, 119, 5405-5416. [CrossRef] [PubMed]

40. Semenza, G.L. Regulation of cancer cell metabolism by hypoxia-inducible factor 1. Semin. Cancer Biol. 2009, 19, 12-16. [CrossRef] [PubMed]

41. Chachami, G.; Paraskeva, E.; Mingot, J.M.; Braliou, G.G.; Gorlich, D.; Simos, G. Transport of hypoxia-inducible factor HIF-1alpha into the nucleus involves importins 4 and 7. Biochem. Biophys. Res. Commun. 2009, 390, $235-240$. [CrossRef] [PubMed]

42. Russell, L.; Naora, H.; Naora, H. Down-regulated RPS3a/nbl Expression during Retinoid-induced Differentiation of HL-60 Cell: A Close Association with Diminished Susceptibility to Actinomycin D-stimulated Apoptosis. Cell Struct. Funct. 2000, 25, 103-113. [CrossRef] [PubMed]

43. Penna, I.; Du, H.; Ferriani, R.; Taylor, H.S. Calpain5 expression is decreased in endometriosis and regulated by HOXA10 in human endometrial cells. Mol. Hum. Reprod. 2008, 14, 613-618. [CrossRef] [PubMed]

44. Chiusolo, V.; Jacquemin, G.; Yonca Bassoy, E.; Vinet, L.; Liguori, L.; Walch, M.; Kozjak-Pavlovic, V.; Martinvalet, D. Granzyme B enters the mitochondria in a Sam50-, Tim22- and mtHsp70-dependent manner to induce apoptosis. Cell Death Differ. 2017, 24, 747-758. [CrossRef] [PubMed]

45. Radke, I.; Gotte, M.; Smollich, M.; Scharle, N.; Kiesel, L.; Wulfing, P. Expression of PRL-3 regulates proliferation and invasion of breast cancer cells in vitro. Arch. Gynecol. Obstet. 2017, 296, 1153-1160. [CrossRef] [PubMed]

46. Rodrigues-Moreira, S.; Moreno, S.G.; Ghinatti, G.; Lewandowski, D.; Hoffschir, F.; Ferri, F.; Gallouet, A.S.; Gay, D.; Motohashi, H.; Yamamoto, M.; et al. Low-Dose Irradiation Promotes Persistent Oxidative Stress and Decreases Self-Renewal in Hematopoietic Stem Cells. Cell Rep. 2017, 20, 3199-3211. [CrossRef] [PubMed]

47. Bakkar, N.; Kousari, A.; Kovalik, T.; Li, Y.; Bowser, R. RBM45 Modulates the Antioxidant Response in Amyotrophic Lateral Sclerosis through Interactions with KEAP1. Mol. Cell. Biol. 2015, 35, 2385-2399. [CrossRef] [PubMed]

(C) 2018 by the authors. Licensee MDPI, Basel, Switzerland. This article is an open access article distributed under the terms and conditions of the Creative Commons Attribution (CC BY) license (http:/ / creativecommons.org/licenses/by/4.0/). 